\title{
Plakalı Kanatçıklı Isı Değiştiricilerde Kanat Geometrisinin Isı Transferine Olan Etkisinin Üç Boyutlu Sayısal Olarak İncelenmesi
}

\section{Ertan BUYRUK¹, Koray KARABULUT*2}

${ }^{1}$ Cumhuriyet Üniversitesi, Mühendislik Fakültesi, Makine Müh. Bölümü, 58140, Sivas

${ }^{2}$ Cumhuriyet Üniversitesi, Mühendislik Fakültesi, Enerji Sistemleri Müh. Bölümü, 58140 , Sivas

(Alınış / Received: 18.07.2016, Kabul / Accepted: 11.01.2017, Online Yayınlanma / Published Online: 02.05.2017)

Anahtar Kelimeler Plakalı isı değiştirici, Sayısal isı transferi, Kanat
Özet: $\mathrm{Bu}$ çalıșmada, plakalı kanatçlklı ıSı değiștiricilerde ıSı transferini artırmak için birleșik ısı transferi yaklașımıyla zikzak (B tipi) ve iç-dış zikzak (C tipi) olmak üzere iki farklı dikdörtgensel kanatçık tipinin isı transferine olan etkileri ve basınç düşüşleri sayısal olarak incelenmiştir. Sayısal hesaplamalar, üç boyutlu Navier-Stokes ve enerji denkleminin FLUENT programı kullanılarak çözülmesiyle zamandan bağımsız olarak elde edilmiștir. Çalışma akışkanı olarak hava kullanılmıştır. Çalışmada, paralel ve ters akış şartlarında Reynolds sayısının farklı değerlerinin ve kanatçı yüksekliğinin ısı transfer artışı üzerindeki etkisi ve ayrıca soğuk ve sıcak akışkanların sıcaklık dağılımları da incelenmiștir. Sonuçlar soğuk akıșkan sıcaklığının ters akış durumunda iç-dış zikzak kanatçıklı kanalda düz kanala göre kanal çıkışında \% 8.4, paralel akış durumunda ise zikzak kanatçıklı kanalda yine düz kanalla karşılaştırıldığında \% 7.6' lık artıș elde edildiğini göstermektedir.

\section{The Three Dimensional Numerical Investigation of the Effect of} Fin Geometry on the Heat Transfer in Plate Fin Heat Exchangers

\section{Keywords}

Plate heat

exchanger,

Numerical heat transfer, Fin
Abstract: In the present study, the effects of two different types of rectangular fins with zigzag (B type) and inner-outer zigzag (C type) for heat transfer enhancement with the use of a conjugated heat transfer approach and pressure drops are numerically evaluated in plate fin heat exchangers. The numerical computations are performed by solving a steady, threedimensional Navier-Stokes equation and an energy equation by using Fluent software program. Air is taken as a working fluid. On heat transfer enhancement the effect of different values of Reynolds number and fin heights and also temperature distributions of the hot and cold fluids are investigated for parallel and counter flow in the study. The results show that cold fluid 
E. Buyruk ve K. Karabulut / Plakalı Kanatçıklı Isı Değiștiricilerde Kanat Geometrisinin Isı Transferine Olan Etkisinin Üç Boyutlu Sayısal Olarak İncelenmesi

temperature is enhanced by $8.4 \%$ at the exit of the channel with inner-outer zigzag fin for counter flow, it is increased by $7.6 \%$ at the exit of the channel with zigzag fin for parallel flow when compared to channel without fin.

*Sorumlu yazar: kkarabulut@cumhurivet.edu.tr, koray.karabulut@hotmail.com

\section{Giris}

Isı değiștiricilerindeki ısı transferini iyileştirme çalışmalarında arzu edilenler; ağırlık ve boyutta azalmaya imkan sağlamak, isı transferi miktarını artırmak, akışkanlar arasındaki ortalama sıcaklık farkını azaltmak ve böylece toplam verimliliği iyileștirmektir. Isı transferini artırmak için kullanılan yöntemler genellikle genişletilmiş yüzeyleri, yüzeyde yapılacak birtakım değişiklikleri, akış alanında oluşturulmak istenen türbülansı içermektedir [1].

Bugünün teknolojisinde isı transferi miktarını artırmada yoğun olarak kullanılan yöntemlerden birisi, genişletilmiş ısı transferi yüzeyleridir (kanatçıklar). Kanatçıklı (genişletilmiş) yüzeyler, yüzey alanını ve akımın türbülansını artırmak suretiyle taşınımla ısı ve kütle aktarımını artırırlar. Kanatçıklı yüzeylerin uygulama alanı çok çeşitlidir. Başlıca kullanım alanları olarak gaz türbin motorlarında türbin kanatçıklarının soğutulması, elektronik cihazların soğutulması ile havacılık, uçak ve kimyasal üretim tesislerindeki çeşitli ısı değiştiricileri sayılabilir. Bununla birlikte, kanatçıkların uygun şekilde kullanılmaması ısı geçişini artırmak yerine azaltabilir. Kanatçık malzemesinin, tipinin, yerleştirilme düzeninin, yüzeye monte şeklinin ve ortam şartlarının her birisinin ayrı ayrı ele alınarak incelenmesi ve ısı geçişini artıracak şekilde değerlendirilmeleri gerekir. Isı değiştiricilerinde transfer edilen ısı miktarının düşmesi, ısı değiştiricinin performansının düşmesine neden olur. $\mathrm{Bu}$ da $\mathrm{s} ı$ değiștiricisi kullanılan sistemde kapasite kaybı anlamına gelmektedir. Isı transferinin iyileștirilmesi, sistem boyutlarının uygun ölçülerde tutulmasına ve dolayısıyla sistem maliyetinin ve ișletme giderlerinin azaltılmasına olanak sağlar. Plakalı ısı değiştiricilerinde, ısı transferi ve akış yapılarını anlamak için birçok teorik ve deneysel çalışma yapılmıştır. Yapılan çalıșmaların bir tanesinde, farklı kurulumlarla oluşturulan kanatçıkları kullanarak, laminer ve düşük türbülansh akış oranları için tablet tipi $1 S 1$ değiştiricilerinde isı transferi artırımı deneysel ve sayısal olarak araştırılmıştır [2]. Lee ve Abdel-Moneim [3] tarafından CFD modelinin kullanılmasıyla iki boyutlu düz dişli yatay yüzeyden olan isı transferi ve akış biçimi sayısal olarak araștırılmıştır. Acharya vd. [4], periyodik olarak gelişen akış alanı için kanatçıklara sahip kanalda akış ve ısı transferini deneysel ve sayisal olarak incelemişlerdir. Liou, Chang ve Hwang [5] ve Liou, Hwang [6] farklı kanatçık yüksekliği ve debilerde, farklı eğim açlarında peş peşe düzenlenmiş iki çift türbülans oluşturucu için araştırmalar yapmışlardır $\left(1.2 \times 10^{4}<\operatorname{Re}<12 \times 10^{4}\right)$. İki boyutlu dikdörtgensel kanala yerleştirilen üç farklı genişletilmiş yüzey geometrisinin isı transferi üzerindeki etkileri Kaya vd. tarafindan araştırılmıştır [7]. Buyruk vd. [8] ve Buyruk ve Karabulut [9], yatay eksende $10 \mathrm{~mm}$ ötelenmiş, $4 \mathrm{~mm}$ kanatçık yüksekliği ve yatay eksenle arasında $30^{\circ}$, $60^{\circ}$ ve $90^{\circ}$ olmak üzere farklı kanatçık açılarına sahip plakalı kanatçıklı ısı değiştiricileri için ısı transferi artışını sayısal olarak incelemişlerdir. Ayrıca, dış zikzak-iç zikzak-düz-diş zikzak ve iç zikzak-düz-iç zikzak olmak üzere farklı dikdörtgensel kanatçı geometri dizilimlerine sahip plakalı kanatçıklı ısı değiştiricilerinde kanatçıksız düz kanala göre ısı transferi artışı Buyruk ve 
E. Buyruk ve K. Karabulut / Plakalı Kanatçıklı Isı Değiștiricilerde Kanat Geometrisinin Isı Transferine Olan Etkisinin Üç Boyutlu Sayısal Olarak İncelenmesi

Karabulut [10] tarafından yapılmıștır. Daha sonra bu dört değerlendirilmiștir. Karabulut vd. [11] optimizasyon parametresinin hassasiyet diğer bir çalışmalarında, $4 \mathrm{~mm}$ kanatçık analizi, Kriging model uyumuna yüksekliğine ve zikzak ve dış zikzak-düz- dayandırılarak gerçekleștirilmiştir. dış zikzak olmak üzere iki farklı kanatçık Masliyah ve Nandakumar [16], sonlu geometrisine sahip plakalı kanatçıklı ıSı değiştiricilerinde isı transferi ve akış yapılarını zamandan bağımsız, üç boyutlu, sayısal olarak incelemişlerdir. Ters akış durumunda zikzak kanatçılklı kanalda kanatçısısız düz kanala göre kanal çıkışında \% 9' luk bir ısı transferi artışı elde etmişlerdir. Çalışmada ayrıca, dıș zikzak-düz-dıș zikzak kanatçıklı kanalda sıcak akışkan için kanatçı yüksekliğinin değişiminin 1 sı transferi üzerindeki etkisi araștırılmıștır. Ngo vd. [12], hem S şekilli kanatçılkl hem de zikzak kanatçıklı mikro kanal ıSı değiştiricileri için Prandtl sayısının 0.75' den 2.2' ye kadar geniş aralıktaki değişimi için Nusselt sayısı ve f sürtünme faktöründen (basınç düşüşü faktöründen) bağımsızlığının araştırmasını karbondioksit çevrimleri için deneysel olarak yapmışlardır. Ganzarolli ve Alternai [13], çalışma akışkanı olarak havayı kullanarak en düşük giriş sıcaklık farkı ve en az sayıdaki entropi üretim birimi şartlarına göre ters akışlı bir ısı değiștiricisinin ısıl dizaynını yapmışlardır. Wang vd. [14], düz ve tırtıklı kanatçıklı plakalı ıSı değiştiricileri için akış ve ısı transferi karakteristiklerini analiz etmişlerdir. Düşük Reynolds sayılarında iki kanatçılklı ısı değiştiricileri için sayısal simülasyonlar CFD kod FLUENT kullanılarak yapılmıştır. Wen vd. [15], Kriging yüzey yöntemini kullanarak testere dişli kanatçıklı plakalı bir ısı değiştiricisinin optimizasyonunu çalışmışlardır. Bu amaçla öncelikle, optimizasyon parametreleri olarak kanatç̧ı kalınlığı $t$, kanatçık aralığı $s$, kanatçık yüksekliği h ve kanal uzunluğu 1 kullanılarak plakalı kanatçıklı ısı değiştiricisinin Colburn (j) ve sürtünme (f) faktörlerini hesaplamak için testere dişli kanatçıkların sayısal simülasyonu elemanlar yöntemini kullanarak üçgen kanatçıklı boruların isı transferi karakteristiklerini elde etmişlerdir. Çalışmalarında en yüksek ısı transferi için kanat kurulumlarında en uygun kanat sayısının olduğu sonucuna varmışlardır. Gupta vd. [17], MAC yöntemini kullanarak sayısal olarak üçgen kanatçıklı plakalı tip bir ısı değiştiricisinde ısı transferi artırımı için bir çift kanatç̧lk tip vorteks üretecinin akış yapısı ve performansını araștırmışlardır. Isı transferinde \% 13 artış elde etmişlerdir. Ayrıca kanatçık çiftinin yüksekliklerini değiştirerek, ISı transferi artış oranını belirlemişlerdir. Salehi vd. [18], kollektör düzenlemesi ve kollektördeki akıș saptırıcının yerleşiminin plakalı kanatçıklı ıSı değiştiricisinin verimliliği üzerindeki etkisini incelemişlerdir. Ayrıca, farklı Reynolds sayılarına karşı Colburn j faktörünü değerlendirerek plakalı kanatçıklı ısı değiștiricileri üzerinde dört farklı üçgen kanatçık dizisinin etkisini incelemek için sayısal olarak çalışmışlardır. Isı değiştiricilerde, ısı transfer plakaları arasında üçgensel kanatçı kurulumunun ISl transferi performansını iyileștirdiği sonucuna varmışlardır. Zhu ve Li [19], dört kanatç̧k tipi için (dikdörtgen, çubuk, oluklu ve dalgalı kanatçık) laminer akış rejiminde, kanatçık kalınlığını dikkate alarak akış yapısı ve ısı transferi üzerinde ısıl giriş ve çıkış etkilerini üç boyutlu sayısal olarak araştırmışlardır. Dixit ve Patil [20] çalışmalarında, genişletilmiş yüzeyler üzerinde çapraz, eğimli, V ve çoklu-V yivli düzenlemelere sahip plakalı kanatçıklı ISı değiştiricilerinin ısı transferi özellikleri hakkında deneysel araştırma sonuçlarını sunmuşlardır. Çalışmada değerlendirdikleri tüm kanatçık tipleri 
E. Buyruk ve K. Karabulut / Plakalı Kanatçıklı Isı Değiștiricilerde Kanat Geometrisinin Isı Transferine Olan Etkisinin Üç Boyutlu Sayısal Olarak İncelenmesi

arasında en yüksek ısı transferi artışı değerine eğimli yivli kanatçık tipinde ulaşmışlardır. En yüksek Nusselt sayısı artışı \% 47 olarak bulunmuştur. Wasewar vd., FLUENT paket programını kullanarak, geleneksel ısı değiştiricisi ile plakalı kanatçıklı ısı değiștiricisini karşılaştırarak akış dağılımını araştırmışlardır [21]. Bhutta vd. [22] ısı değiştiricilerin dizaynında karşılaşılan çeşitli problemler ve bu problemlerin CFD yardımıyla çözülebilmesi için hazır bir kaynak olarak kullanılabilecek bir derleme çalışması yapmışlardır.

Literatürde belirtilen çalışmalar incelendiğinde, bu çalışmada değerlendirilen kanatçık tiplerine henüz değinilmediği görülmüştür. $\mathrm{Bu}$ çalışmada, plakalı kanatçıklı ısı değiştiricileri için özgün kanatçık geometrileri üzerinde çalışılmıştır. $\mathrm{Bu}$ nedenle daha yüksek ısı transferi oranları elde etmek için dikdörtgensel tipteki bu kanatçık geometrilerinin isı transfer performans özelliklerini araştırmak amacıyla sunulan çalışmada farklı tipteki zikzak ve iç-dış zikzak kanatçıkların ısı transferi ve akış yapısı üzerindeki etkileri araştırılmıştır. Literatürde belirtilen çalışmalardan Ngo vd. [12] yaptıkları çalışmada mikro kanal ısı değiştiricisinde paslanmaz çelikten imal edilmiş sı aralıklı zikzak kanatçıklar kullanırken, bu çalışmada yalnızca 12 adet tek aralıktan oluşan alüminyum kanatçıklarla ısı transferi artışı elde edilmiştir. Çalışmada ayrıca, kanatçık yüksekliğinin soğuk akışkan sıcaklığı üzerindeki etkisi dikkate alınmış ve kanalın alt ve üst yüzeylerinde oluşan sıcak ve soğuk akışkan sicaklık dağılımları da görselleştirilmiştir. Bununla birlikte, farklı Reynolds sayılarının Nusselt sayısı üzerindeki etkisi de incelenmiştir. Hesaplamalar, FLUENT paket programı kullanılarak yapılmıștır. Sonuçlar, düz kanalla kanatçıklı kanalların karşılaştırılmasıyla sıcaklık dağılımları, noktasal sıcaklık ve
Nusselt sayısı değişimleri olarak farklı kanatçık geometrileri, kanatçık yükseklikleri ve akış tipleri için sunulmuştur.

\section{Sayısal Yöntem}

Sayısal çalışma üç boyutlu, zamandan bağımsız, birleşik (iletim ve taşınım) ısı transferi yaklaşımıyla çözülmüştür. Birleşik ısı transferi analizini çözmek için sonlu hacimler yöntemi (FLUENT programı) kullanılmıștır.

Sonlu hacimler yöntemi, çözülecek geometriyi parçalara bölerek bu parçaların her biri için çözüm yapma ve daha sonra bu çözümleri birleștirerek problemin genel çözümünü bulma esasına dayanır. Sonlu hacimler yöntemi, korunum denklemlerini sayısal olarak çözümlenebilen cebirsel denklem sistemlerine dönüştürmek için kontrol hacim esaslı bir teknik kullanır. Bu teknik her bir kontrol hacmi için korunum denklemlerinin integrasyonunun alınması sonucunda, değişkenler için kontrol hacmini sağlayan ayrık eşitliklerin elde edilmesini içerir. Ayrık eşitliklerin doğrusallaştırılması ile elde edilen, doğrusal denklem sistemlerinin iterasyona bağlı çözümü ile hız, basınç ve sıcaklık gibi değişkenler verilen yakınsaklık ölçüsünü sağlayıncaya kadar güncellenir. Hazırlanabilecek en uygun ağ yapısı için hız, basınç ve sıcaklık değişiminin fazla olduğu bölgelerde daha sık ağ yapısı oluşturulmalıdır. $\mathrm{Bu}$ nedenle, kanatların olduğu kanal yüzeyleri en sık ağ yapısının olduğu kısımlardır ve diğer bölgelerde daha seyrek ağ yapısı tercih edilmiștir. Sayısal modelde, kanalın kanatlı kısımlarının da olduğu katı bölgede 25000 hücreden oluşan dikdörtgensel ağ yapısı varken, akışkanın olduğu üst ve alt kanal kısımlarında 74000 elemandan oluşan dikdörtgensel ağ yapısı kullanılmış ve ayrıca sonuçların ağ yapısından bağımsızlığı da sağlanmıştır. Bununla birlikte, bu çalışmadaki hesaplamalarda 
E. Buyruk ve K. Karabulut / Plakalı Kanatçıklı Isı Değiștiricilerde Kanat Geometrisinin Isı Transferine Olan Etkisinin Üç Boyutlu Sayısal Olarak İncelenmesi

standart $\quad k-\varepsilon \quad$ türbülans modeli -Enerji denklemi

kullanılmıştır.

Kullanılan kanatçıklar türbülansa neden olduğundan sayısal hesaplamalarda seçilen kanatçıklı geometriler için standart $k-\varepsilon$ türbülans modelinin uygun olduğu belirlenmiştir.

Geometri boyunca akış ve ısı transferinin çözümlemesi, zamandan bağımsız olarak kütlenin (süreklilik denklemi), momentumun ve enerjinin korunumu kanunlarından elde edilen kısmi türevli denklemlerin çözümlenmesi esasına dayanır ve şu şekilde yazılabilir $[14,23]$.

-Süreklilik denklemi

$u \frac{\partial T}{\partial x}+v \frac{\partial T}{\partial y}+w \frac{\partial T}{\partial z}=$

$\left(\frac{k}{\rho c_{p}}\right)\left(\frac{\partial^{2} T}{\partial x^{2}}+\frac{\partial^{2} T}{\partial y^{2}}+\frac{\partial^{2} T}{\partial z^{2}}\right)$

Bu denklemlerde, $\rho$ yoğunluk, $\mu$ dinamik viskozite, $p$ basınç, $k$ isıl iletkenlik, $T$ sıcaklık, $c_{p}$ özgül ısı ve $u, v, w$ ise sırasıyla $\mathrm{x}, \mathrm{y}$ ve $\mathrm{z}$ yönlerindeki hızlardır.

Kullanılan standart $k-\varepsilon$ türbülans modelinde, türbülans kinetik enerji, $k$, dissipasyon terimi, $\varepsilon$, ve viskoz kaybolma terimi, $\phi$, kullanılmaktadır.

$\frac{\partial u}{\partial x}+\frac{\partial v}{\partial y}+\frac{\partial w}{\partial z}=0$

-Momentum

Daimi akış için türbülans kinetik enerjisi denklemi,

$\frac{\partial(\rho u k)}{\partial x}+\frac{\partial(\rho v k)}{\partial y}+\frac{\partial(\rho w k)}{\partial z}=$

x momentum denklemi

$\frac{\partial}{\partial x}\left(\frac{\mu_{t}}{\sigma_{k}} \frac{\partial k}{\partial x}\right)+\frac{\partial}{\partial y}\left(\frac{\mu_{t}}{\sigma_{k}} \frac{\partial k}{\partial y}\right)+$

$\rho\left(u \frac{\partial u}{\partial x}+v \frac{\partial u}{\partial y}+w \frac{\partial u}{\partial z}\right)=$

$\frac{\partial}{\partial z}\left(\frac{\mu_{t}}{\sigma_{k}} \frac{\partial k}{\partial z}\right)+\mu_{t} \phi-\rho \varepsilon$

$-\frac{\partial p}{\partial x}+\mu\left(\frac{\partial^{2} u}{\partial x^{2}}+\frac{\partial^{2} u}{\partial y^{2}}+\frac{\partial^{2} u}{\partial z^{2}}\right)$

y momentum denklemi

$$
\begin{aligned}
& \rho\left(u \frac{\partial v}{\partial x}+v \frac{\partial v}{\partial y}+w \frac{\partial v}{\partial z}\right)= \\
& -\frac{\partial p}{\partial y}+\mu\left(\frac{\partial^{2} v}{\partial x^{2}}+\frac{\partial^{2} v}{\partial y^{2}}+\frac{\partial^{2} v}{\partial z^{2}}\right)
\end{aligned}
$$

z momentum denklemi

$$
\begin{aligned}
& \rho\left(u \frac{\partial w}{\partial x}+v \frac{\partial w}{\partial y}+w \frac{\partial w}{\partial z}\right)= \\
& -\frac{\partial p}{\partial z}+\mu\left(\frac{\partial^{2} w}{\partial x^{2}}+\frac{\partial^{2} w}{\partial y^{2}}+\frac{\partial^{2} w}{\partial z^{2}}\right)
\end{aligned}
$$

Türbülans viskozitesi

$$
\mu_{t}=C_{\mu} \cdot \rho \cdot \frac{k^{2}}{\varepsilon}
$$

Türbülans kinetik enerji

$$
k=\frac{1}{2}\left(\overline{u^{\prime 2}}+\overline{v^{\prime 2}}+\overline{w^{\prime 2}}\right)
$$

Viskoz kaybolma terimi

$$
\phi=2 \mu\left[\left(\frac{\partial u}{\partial x}\right)^{2}+\left(\frac{\partial v}{\partial y}\right)^{2}\right]+\mu\left(\frac{\partial v}{\partial x}+\frac{\partial u}{\partial y}\right)^{2}(7)
$$


E. Buyruk ve K. Karabulut / Plakalı Kanatçıklı Isı Değiștiricilerde Kanat Geometrisinin Isı Transferine Olan Etkisinin Üç Boyutlu Sayısal Olarak İncelenmesi

Türbülans kinetik enerji kaybolma Kanat malzemesinin ısıl iletkenliği kanal denklemi

$$
\begin{aligned}
& \frac{\partial(\rho u \varepsilon)}{\partial x}+\frac{\partial(\rho v \varepsilon)}{\partial y}+\frac{\partial(\rho w \varepsilon)}{\partial z}= \\
& \frac{\partial}{\partial x}\left(\frac{\mu_{t}}{\sigma_{\varepsilon}} \frac{\partial \varepsilon}{\partial x}\right)+\frac{\partial}{\partial y}\left(\frac{\mu_{t}}{\sigma_{\varepsilon}} \frac{\partial \varepsilon}{\partial y}\right)+ \\
& \frac{\partial}{\partial z}\left(\frac{\mu_{t}}{\sigma_{\varepsilon}} \frac{\partial \varepsilon}{\partial z}\right)+C_{1 \varepsilon} \mu_{t} \frac{\varepsilon}{k^{\prime}} \phi-C_{2 \varepsilon} \rho \frac{\varepsilon^{2}}{k^{\prime}}
\end{aligned}
$$

$C_{\mu}, C_{1 \varepsilon}, C_{2 \varepsilon}, \sigma_{k}$ ve $\sigma_{\varepsilon}$ katsayıları sabit olup $C_{\mu}=0.09, C_{1 \varepsilon}=1.44, C_{2 \varepsilon}=1.92, \sigma_{k}=1 \mathrm{ve}$ $\sigma_{\varepsilon}=1.3$ 'dür.

Reynolds sayısı

$$
R e=\frac{V_{\infty} \cdot D_{h}}{v}
$$

Burada, $D_{h}$ kanalın hidrolik çapıdır.

$$
D_{h}=\frac{4 A_{c}}{P}=\frac{4\left(H_{2} \cdot W\right)}{2\left(H_{2} \cdot W\right)}
$$

$A c$ kanalın kesit alanı, $P$ ise kanalın çevre uzunluğudur.

Sınır şartı ve Nusselt sayısı aşağıdaki şekilde verilmiştir.

$$
\begin{aligned}
& -k\left(\frac{d T}{d n}\right)_{\text {yüzey }}=h\left(T_{\infty}-T_{s}\right) \text { ve } \\
& N u=\frac{h \cdot D_{h}}{k}
\end{aligned}
$$

h yüzey ısı taşınım katsayısıdır.

Basınç düşüşü aşağıdaki şekilde hesaplanabilir

$$
\Delta P_{L}=f \cdot \frac{L}{D_{h}} \cdot \frac{\rho \cdot V_{m}^{2}}{2}
$$

$\Delta P_{L}$ akış yönünde kanaldaki basınç düşüşü, f ise sürtünme faktörüdür. boyunca ısıl dağılımı etkilediği için, ısı transferini artırmada kanat malzemesinin seçimi önemli bir faktördür. $\mathrm{Bu}$ nedenle, kanal malzemesi olarak yüksek ısıl iletkenliğe sahip, ucuz ve hafif olan alüminyum seçilmiștir. Kanatların kanal yüzeyi ile bir bütün olarak üretildiği varsayılarak, kanatlar ve yüzey arasındaki ısıl direnç ihmal edilmiştir.

\section{Geometrik Model}

Şekil 1' de üç boyutlu düz kanal geometrisinin perspektif görünüşü gösterilmekte iken, Şekil 2a ve Şekil 2b' de ise sırasıyla sayısal hesaplamalarda kullanılan zikzak ve iç-dıș zikzak kanatçık modellerine ait dikdörtgensel kanal geometrileri gösterilmektedir. Ayrıca, bu şekiller üzerinde sınır şartları da belirtilmiştir. Şekil 2a ve Şekil 2b' de kanatçıkların daha iyi görselleştirilebilmesi için kanalın ters çevrilmiş görüntüsü konulmuştur.

Kanatçık şekli

:Dikdörtgensel

zikzak ve iç-dış zikzak

Kanatçık yüksekliği (e) : :2 mm, 4 mm

Kanatçık aralığı (b) : :10, 20, $30 \mathrm{~mm}$

Kanatçık genişliği (a) : $3 \mathrm{~mm}$

Kanatçı açısı (Ф) : : $90^{\circ}$

Kanal boyu (L) : $300 \mathrm{~mm}$

Kanal genişliği (W) : $150 \mathrm{~mm}$

Üst kanal yüksekliği $\left(\mathrm{H}_{1}\right)$ : $5 \mathrm{~mm}$

Alt kanal yüksekliği ( $\left.\mathrm{H}_{2}\right) \quad$ : $10 \mathrm{~mm}$

Katı yüzey kalınlığı $(\mathrm{t}) \quad: 2 \mathrm{~mm}$

Reynolds sayısı : : 300, 400, 700

Sıcak akışkan sıcaklığ $\left(\mathrm{T}_{\mathrm{h}}\right): 600 \mathrm{~K}$

Soğuk akışkan sıcaklı̆̆l $\left(\mathrm{T}_{\mathrm{c}}\right): 300 \mathrm{~K}$

Sıcak hava giriș hızı $\left(\mathrm{V}_{\mathrm{h}}\right) \quad: 1.338 \mathrm{~m} / \mathrm{s}$

Soğuk hava giriş hızı $\left(\mathrm{V}_{\mathrm{c}}\right) \quad: 0.69 \mathrm{~m} / \mathrm{s}$

$\mathrm{Bu}$ çalışmada, düşük hızlarda kanatçık kullanımının ısı aktarımına etkisini görebilmek amacıyla Reynolds sayısının 400 olduğu değerdeki sonuçlar sunulmuştur. Ayrica farklı Reynolds sayılarının ISı transferi üzerindeki etkisini görebilmek için Reynolds 
E. Buyruk ve K. Karabulut / Plakalı Kanatçılklı Isı Değiștiricilerde Kanat Geometrisinin Isı Transferine Olan Etkisinin Üç Boyutlu Sayısal Olarak İncelenmesi

sayısının 300 ve 700 olduğu değerler için de araştırma yapılmıştır. Her iki kanatçık geometrisi için kanala 12 adet kanatçık yerleştirilmiş iken, kanatçık yükseklikleri 2 mm' dir. Ayrıca, zikzak kanatçıklı kanal durumunda kanatçıklar arası mesafe 20 mm iken (Şekil 2a), iç-dış zikzak kanatçılara sahip kanalda ise farklı tipteki kanatçıkların yerleşimi nedeniyle kanatçıklar arası mesafe Şekil 2b' de gösterildiği gibi $10 \mathrm{~mm}, 20 \mathrm{~mm}$ ve 30 mm' dir. i) Akış üç boyutlu, zamandan bağımsız ve laminerdir;

ii) Kullanılan akıșkan sıkıștırılamazdır;

iii)Kanatçık ve kanal malzemesi olarak alüminyum kullanılmıştır;

iv) Tabakalar arası ısıl temas tamdır;

v)Kanalın alt ve üst bölümü için kullanılan akışkan havadır;

vi) Akışkanın ısıl özellikleri sabittir; vii)Hem akışkan hem de katı malzeme için ısı üretimi söz konusu değildir.

$\mathrm{Bu}$ çalışma, belirtilen kabuller altında yapılmıştır:

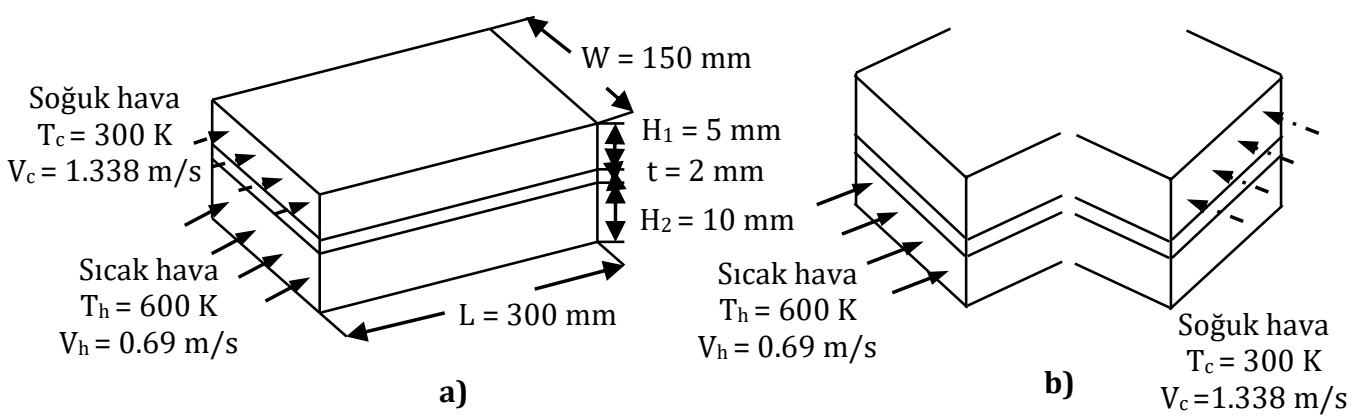

Şekil 1. Düz kanal için perspektif görünüş a) paralel akış b) ters akış

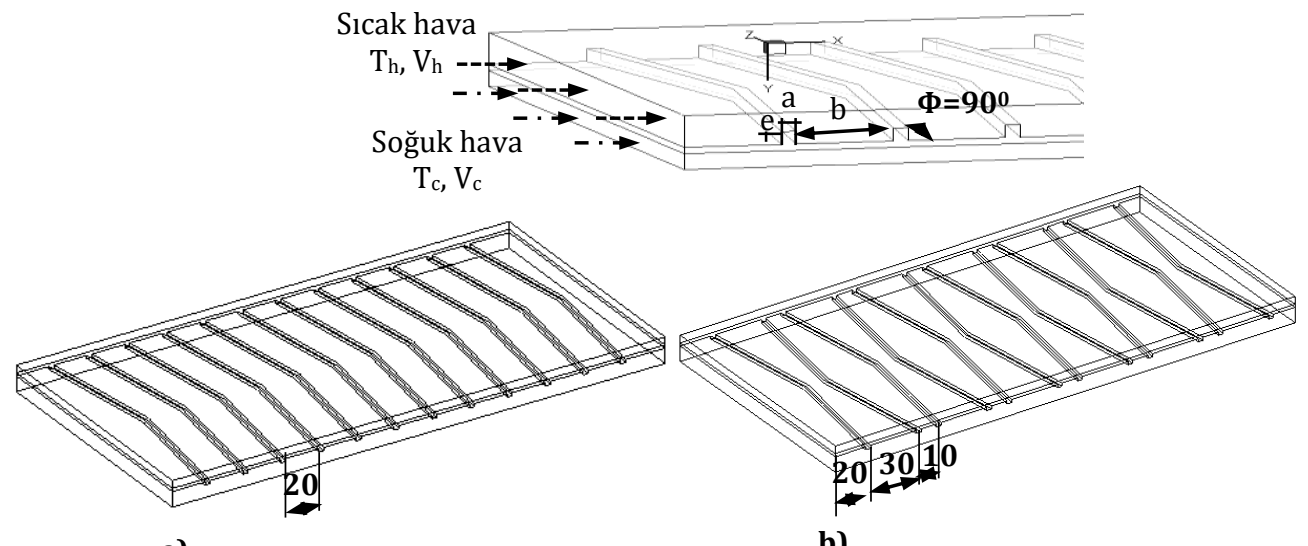

a)

b)

Şekil 2. Sayısal hesaplamalarda kullanılan dikdörtgensel kanal modelleri a) Zikzak, e = $2 \mathrm{~mm}$ b) İç-dışz zikzak, e= $2 \mathrm{~mm}$

\section{Sonuçların Değerlendirilmesi}

Şekil 3' de Kayatas ve Ilbas [24] tarafından yapılan çalışma ile sunulan çalışmanın (Buyruk ve Karabulut) sonuçları karşılaştırılmıştır. Grafikten de görüldüğü gibi sonuçlar birbiriyle uyumludur ve bu nedenle sayisal sonuçların doğru ve kabul edilebilir olduğu sonucuna varılmıştır. Akışkanlar arasındaki sıcaklık farklılığının, ağ 
E. Buyruk ve K. Karabulut / Plakalı Kanatçıklı Isı Değiştiricilerde Kanat Geometrisinin Isı Transferine Olan Etkisinin Üç Boyutlu Sayısal Olarak İncelenmesi

yapisindan

düşünülmektedir.

kaynaklandığı

Sunulan çalışmanın sonuçlarının ă̆ yapısından olan bağımsızlığını belirlemek için kanatçıklı bir kanalda dikdörtgensel ağ eleman sayısı değiștirilerek sonuçların değișimi incelenmiştir (Şekil 4). Kanal kesitinde

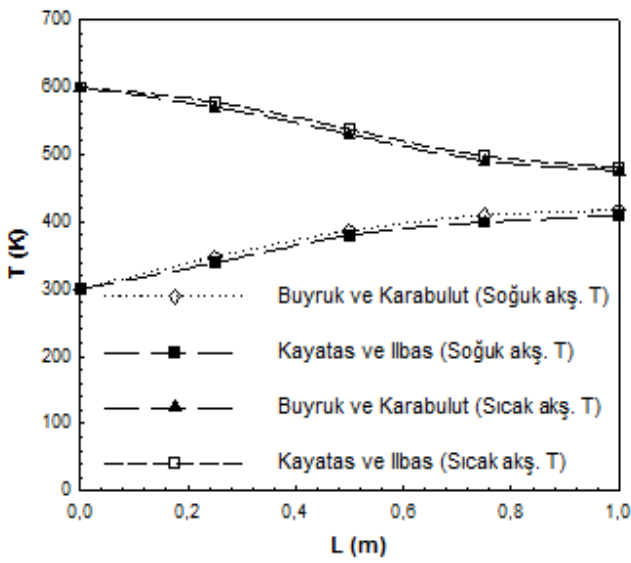

Şekil 3. Kanatçıklı kanal için Kayatas ve Ilbas' ın çalışması ile sunulan çalışmanın karşılaştırııması

Şekil 5A ve 5B' de sırasıyla soğuk ve sıcak akışkanlar için paralel ve ters akış durumlarında düz kanal, zikzak kanatçıklı kanal (B-tipi) ve iç-dış zikzak kanatçıklı kanal (C-tipi) için üç boyutlu sıcaklık dağılımları gösterilmektedir. Paralel akış için kanalın giriş kısmında yüksek ısı transferi oranı elde edilirken, kanalın çıkış kısmına doğru soğuk ve sıcak akışkanlar arasındaki sıcaklık farkının azalması nedeniyle bu oran azalmaktadır. Bununla birlikte ters akış için soğuk akıșkan sürekli sıcak akışkana karşı hareket ettiğinden ısı transferi artmaya devam etmektedir. Bu nedenle, Şekil $5 A$ ve $5 B^{\prime}$ de de görülebildiği gibi hem soğuk hem de sıcak akışkan için ters akıș durumunda paralel akışa göre daha fazla sıcaklık kontörü değișimi elde edilmektedir. Aynı zamanda, Şekil 5A' da
99000 adet elemanın (kanatçıklı katı kısımda 25000, havanın geçtiği kısımda 74000 adet eleman) olduğu ağ yapısının yeterli olduğu sonucuna varılmıştır (110000 adet elemanın olduğu sonuçla karşılaştırıldığında fark \% 0.1' den daha azdir).

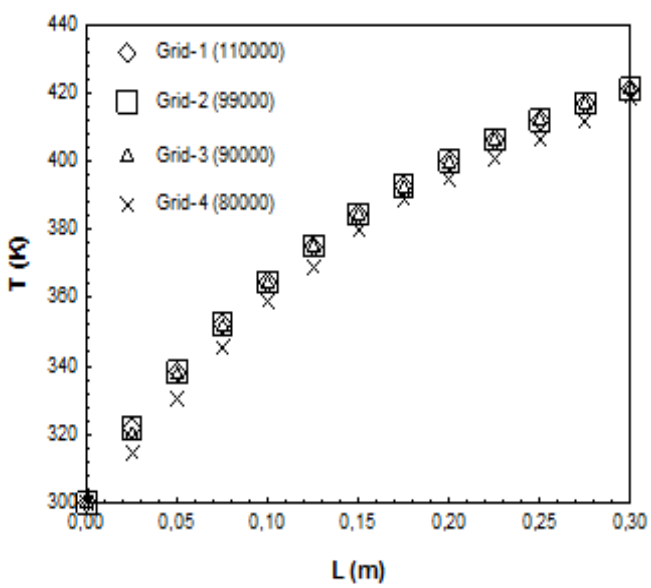

Şekil 4. Soğuk akışkan için ağ yapısının sıcaklık değişimine etkisi

görüldüğü gibi paralel akıșta zikzak kanatçıklı (B-tipi) kanal için soğuk akışkanın sıcaklık değişimi iç-dış zikzak (C-tipi) kanatçıklı kanalınkinden daha fazla iken, ters akış durumunda kanatçıkların türbülans etkisi nedeniyle iç-dış zikzak (C-tipi) kanatçıklı kanaldan daha düşük olmaktadır. Bunun sonucunda, paralel akış için B tipi kanatçlk durumunda C tipindeki kanatçıklı kanalla karşılaştırıldığında sıcak akışkan sıcaklık değișiminin daha fazla olduğu görülmektedir (Şekil 5B). Dahası, her iki kanatçık tipine ait akışkanların sıcaklık değișimlerinin düz kanala göre oldukça fazla olduğu sıcaklık dağılımlarından açıkça görülebilmektedir. Ayrıca, akışkanların, akış yönleri de şekiller üzerinde oklarla belirtilmektedir. 


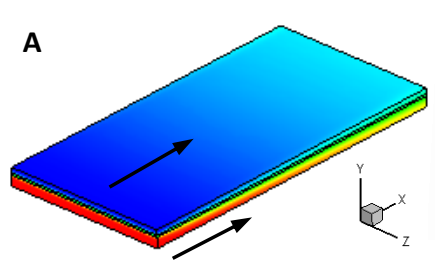

(a) Paralel akış

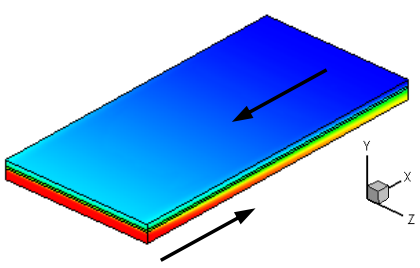

(b) Ters akış

a)

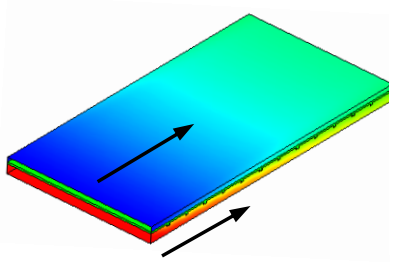

(a) Paralel akış

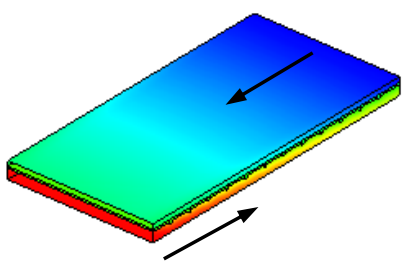

(b) Ters

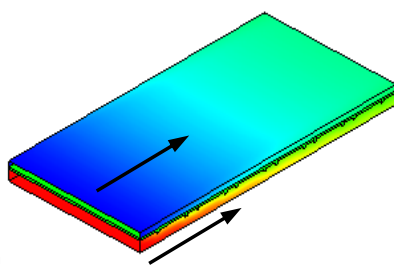

(a) Paralel akış

\section{Sicakllk K}

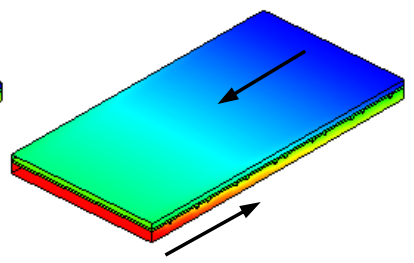

(b) Ters

c)

Şekil 5A. Soğuk akışkan için üç boyutlu sıcaklık dağııımı a) Düz kanal

b) Zikzak kanatçıkı kanal $(e=2 \mathrm{~mm})$ c) iç̧-dış zikzak kanatçıklı kanal $(e=2 \mathrm{~mm})$

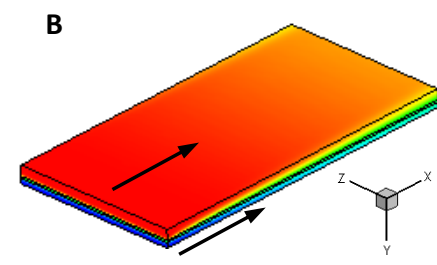

(a) Paralel

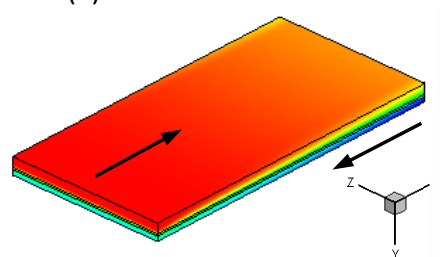

(b) Ters akış

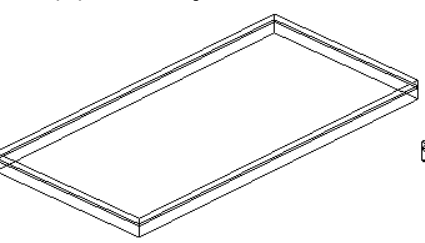

a)

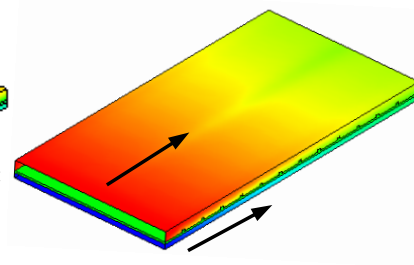

(a) Paralel akış

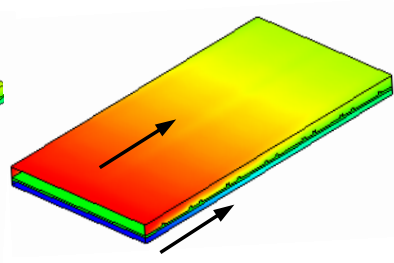

(a) Paralel akış

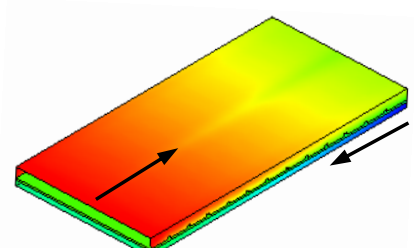

(b) Ters akış

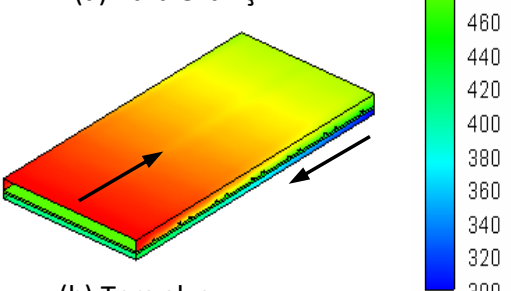

(b) Ters akış

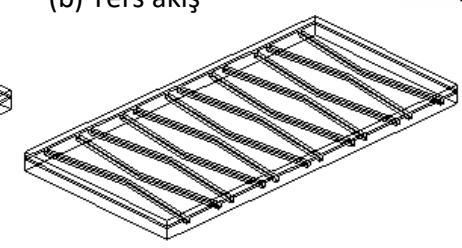

c)

Şekil 5B. Sıcak akışkan için üç boyutlu sıcaklık dağılımı a) Düz kanal

b) Zikzak kanatçıkı kanal $(\mathrm{e}=2 \mathrm{~mm})$ c) icç-dış zikzak kanatçıklı kanal $(\mathrm{e}=2 \mathrm{~mm})$ 
E. Buyruk ve K. Karabulut / Plakalı Kanatçılılı Isı Değiștiricilerde Kanat Geometrisinin Isı Transferine Olan Etkisinin Üç Boyutlu Sayısal Olarak İncelenmesi

Soğuk akışkan için kanal boyunca paralel ve ters akış durumunda sıcaklık değişimi Şekil 6' da gösterilmiştir. Şekilden de görüldüğü gibi düz kanalla karşılaştırıldığında, kanatçıkların kullanımı ısı transfer yüzey alanını ve akışın türbülansını artırmasıyla sıcak akışkandan soğuk akışkana olan isı transferini artırmaktadır. Bunun yanında, B tipi kanatçık için paralel akış durumunda kanal çıkışında soğuk akışkan sıcaklığında kanatçıksız düz kanala göre \% 7.6' lık artış elde edilirken, C tipi kanatçık için \% 6.8' lik bir artış elde edildiği görülmektedir. Ters akış durumunda ise $\mathrm{C}$ tipi kanatçık kullanılması durumunda daha yoğun akış dalgalanmaları elde edilmesiyle B tipi kanatçığa göre daha yüksek soğuk akışkan çıkış sıcaklığına ulaşılmaktadır. Düz kanalla karşılaştırıldığında C tipi kanatçık durumunda sıcaklıktaki artış

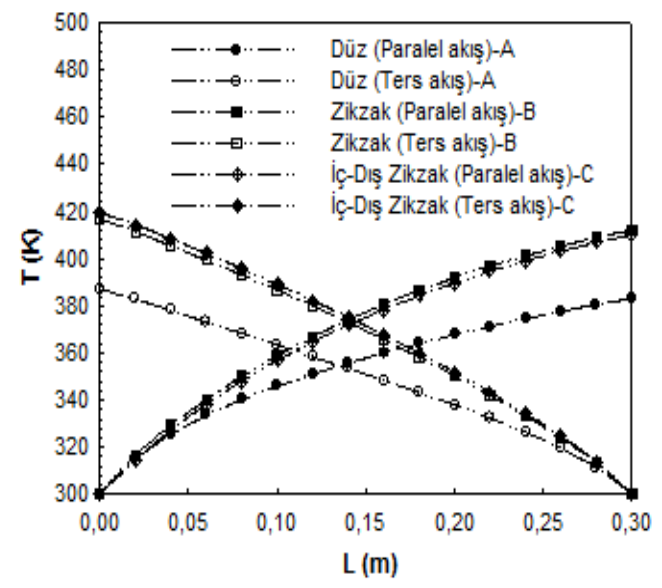

Şekil 6. Paralel ve ters akışta kanal boyunca soğuk akışkan sıcaklık değişimi $(e=2 \mathrm{~mm})$

Şekil 8a ve 8b' de paralel akış için kanal yüzeyi boyunca farklı Reynolds sayılarında sırasıyla noktasal Nusselt sayısı ve soğuk akışkan sıcaklık değişimi gösterilmektedir. Şekil 8a' da görüldüğü gibi noktasal Nusselt sayısı değerleri kanal çıkışına doğru sıcak ve soğuk akışkanlar arası sıcaklık farkının azalmasıyla azalmaktadır. Bununla birlikte Reynolds sayısının artışıyla miktarı \% 8.4 iken B tipi kanatçık için \% 7.7 olmaktadır.

Düz, zikzak (B tipi) ve iç-dış zikzak (C tipi) kanatçık kullanılması durumunda kanal boyunca sıcak akışkan sıcaklık değişimleri paralel ve ters akış için Şekil 7' de gösterilmektedir. Soğuk akışkana olan ısı transferinin artmasıyla kanal boyunca sıcak akışkan sıcaklığ azalmaktadır. Paralel akış için B tipi kanatçık durumunda kanal çıkışında düz kanalla karşılaştırıldığında sıcak akışkan sıcaklığındaki azalma \% 7.7 iken, bu değer C tipi kanatçık durumunda \% 6.75' e düşmektedir. Ters akış durumunda ise sıcaklıktaki bu düșüș değeri iç-dıș zikzak kanatçıklı kanalda yaklaşık olarak \% 10.3' e çıkmaktadır. Böylece ters akış durumunda C tipi kanatçık için daha yüksek soğuk akışkan çlkış sıcaklık değerine ulaşılmaktadır.

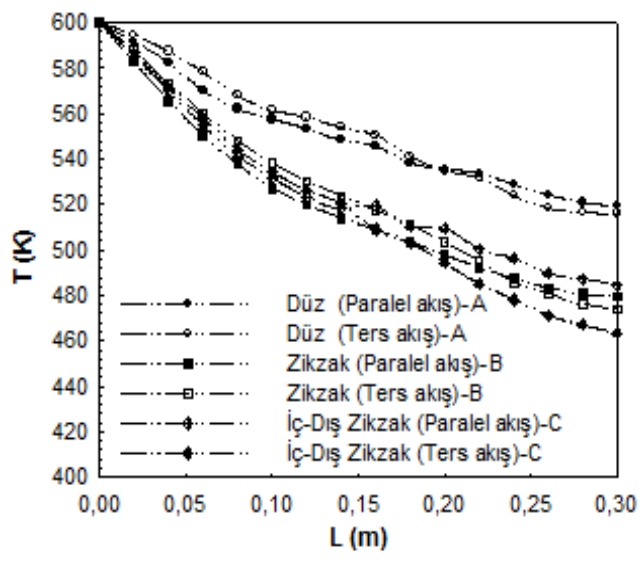

Şekil 7. Paralel ve ters akışta kanal boyunca sıcak akışkan sıcaklık değişimi ( $=2 \mathrm{~mm}$ )

Nusselt sayısı artış göstermektedir. En yüksek Nusselt sayısı değerine, $\mathrm{Re}=700$ olduğu durumda zikzak kanatçıklı kanal için ulaşılmaktadır. Şekil 8b' de gösterilen kanal yüzeyi boyunca sıcaklık değişimi incelendiğinde sıcaklık farkının fazla olduğu kanal girişinde yüksek sıcaklık değerleri elde edilirken, kanal çıkışına doğru ısı transferinin azalması sonucu yüzey sıcaklık değeri de 
E. Buyruk ve K. Karabulut / Plakalı Kanatçıklı Isı Değiştiricilerde Kanat Geometrisinin Isı Transferine Olan Etkisinin Üç Boyutlu Sayısal Olarak İncelenmesi

azalmaktadır. C tipi kanatçıklı kanal durumunda $\mathrm{Re}=700^{\prime}$ de kanal girișinden $0.05 \mathrm{~m}$ uzaklıkta sicaklık değeri $444.5 \mathrm{~K}$ iken $\quad 0.15 \quad \mathrm{~m}$ uzaklıkta $440 \quad \mathrm{~K}^{\prime} \quad \mathrm{e}$ düşmektedir.

Kanal yüzeyi boyunca soğuk akışkan için ters akış durumunda farklı Reynolds sayılarında noktasal Nusselt sayısı ve sıcaklık değişimi sırasıyla Şekil 9a ve 9b' de gösterilmektedir. Ters akış için akıșkanlar arası sıcaklık farkı kanal çıkışında en yüksek değerde

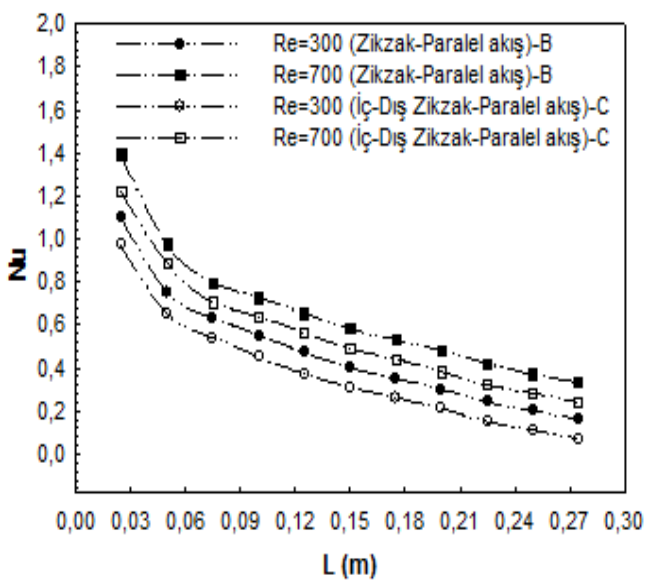

Şekil 8a. Paralel akış durumunda soğuk akışkan için farklı Reynolds sayılarında kanal yüzeyi boyunca noktasal Nusselt sayısı değişimi

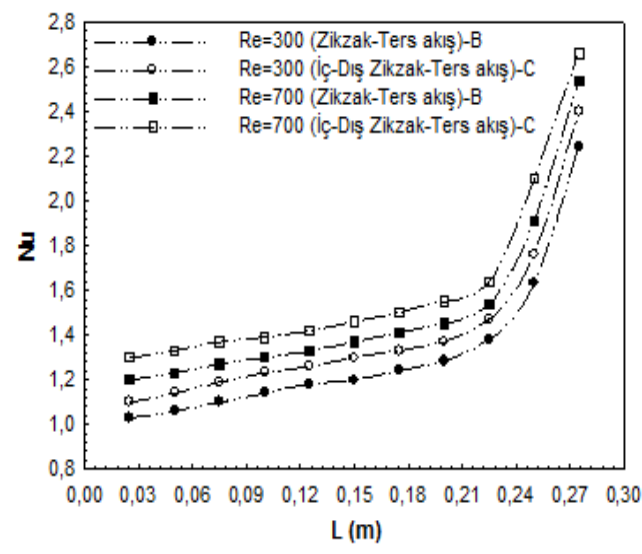

Şekil 9a. Ters akış durumunda soğuk akışkan için farklı Reynolds sayılarında kanal yüzeyi boyunca noktasal Nusselt sayısı değişimi kısmına doğru soğuk akışkan sıcaklığı arttığı için noktasal Nusselt sayısı değerlerinin azaldığı Sekil 9a' dan açıkça görülebilmektedir. Ters akış durumunda en yüksek sıcaklık ve Nusselt sayısı değerlerine iç-dış zikzak kanatçıklı kanal durumunda ve $\operatorname{Re}=700$ değerinde ulaşılmaktadır (Şekil 9a,b). Bu sonuç, ters akış için iç-dış zikzak kanatçıklı kanal durumunda türbülans etkisi ve dolayısıyla ısı transferi artışının zikzak kanatçıklı kanala göre daha yüksek olduğunu göstermektedir.

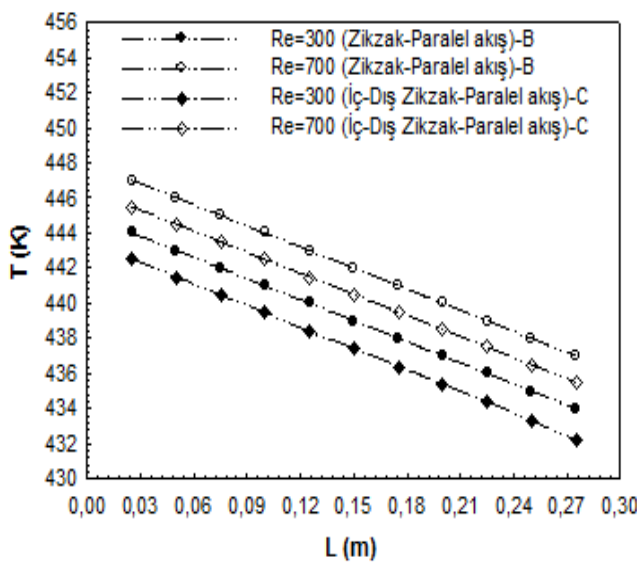

Şekil 8b. Paralel akış durumunda soğuk akışkan için farklı Reynolds sayılarında kanal yüzeyi boyunca soğuk akışkan sıcaklık değişimi

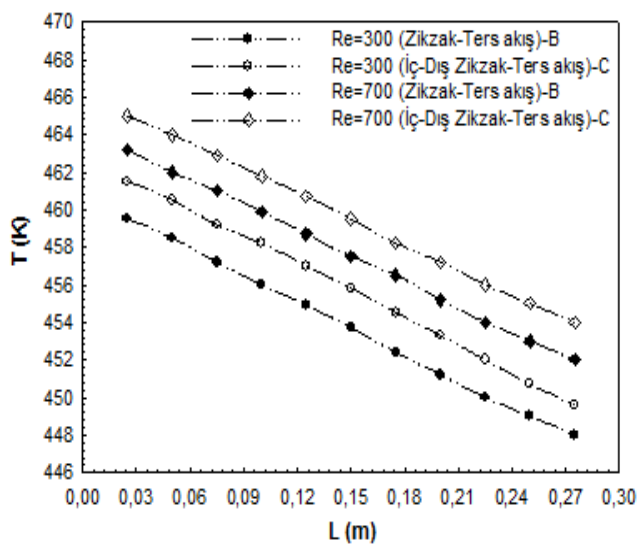

Şekil 9b. Ters akış durumunda soğuk akışkan için farklı Reynolds sayılarında kanal yüzeyi boyunca soğuk akışkan sıcaklık değişimi 
E. Buyruk ve K. Karabulut / Plakalı Kanatçıklı Isı Değiştiricilerde Kanat Geometrisinin Isı Transferine Olan Etkisinin Üç Boyutlu Sayısal Olarak İncelenmesi

Zikzak (B tipi) ve iç-dış zikzak kanatç̧ılı (C-tipi) kanalın soğuk ve sıcak akışkanların geçtiği kısımlarındaki yüzey sıcaklık dağılımları paralel ve ters akış için Şekil 10A ve 10B' de sıcaklık dağllımları üzerinde akış yönleri oklarla da belirtilerek gösterilmektedir. Kanatçılklar nedeniyle akışta meydana gelen türbülans akımları, ısı transfer oranını artırmaktadır. Bu artışın sonucu

A

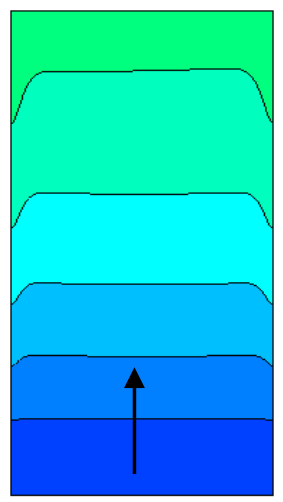

Soğuk Akışkan

a)

B

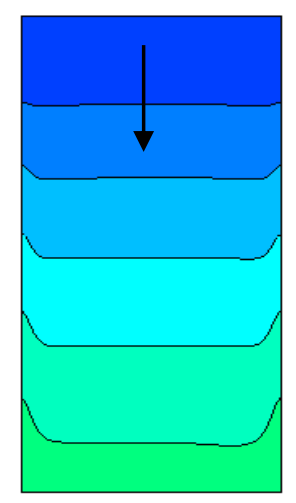

Soğuk Akışkan

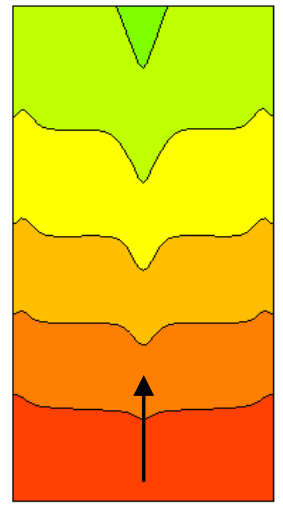

Sıcak Akışkan

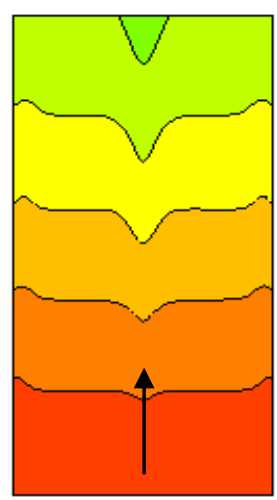

Sıcak Akışkan a)

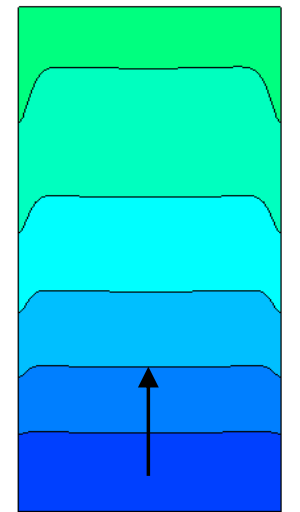

Soğuk Akışkan olarak, paralel akış durumunda B kanatçıktipli kanal için sıcaklık değişimi C tipi kanatçıklı kanaldan daha önce gelişim göstermektedir. $\mathrm{Bu}$ nedenle, paralel akış için B tipi kanatçıklı kanalda daha yüksek sıcaklık değişimi elde edilmektedir (Şekil 10A). Ters akıș durumunda ise bu sıcaklık değișimi B tipi kanatçıklı kanal ile kıyaslandığında C tipi kanatçıklı kanalda daha erken gelişim göstermektedir (Şekil 10B).

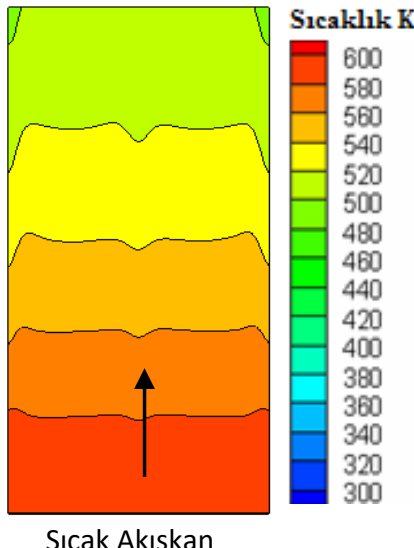

b)

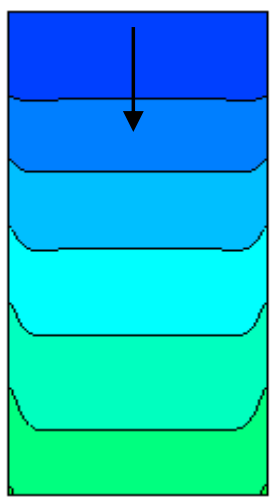

Soğuk Akışkan

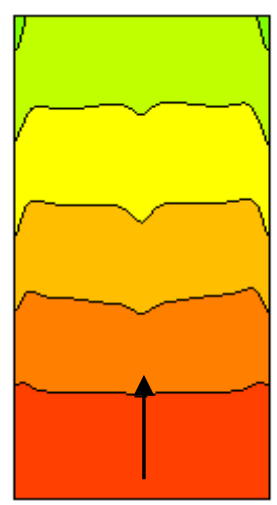

Sıcak Akışkan
Sicaklık K

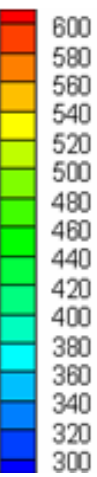

b)

Şekil 10. Kanalın soğuk ve sıcak akışkan taraflarındaki sıcaklık dağılımları A-Paralel akış B-Ters akış a) Zikzak, b) iç̧-dış zikzak 
E. Buyruk ve K. Karabulut / Plakalı Kanatçıklı Isı Değiștiricilerde Kanat Geometrisinin Isı Transferine Olan Etkisinin Üç Boyutlu Sayısal Olarak İncelenmesi

Kanalın soğuk akışkanın geçtiği üst yüzeyindeki sıcaklık değişimleri A, B ve C kanatçık tipli kanallar ve her iki akış durumu için Şekil 11' de gösterilmektedir. Paralel akış durumunda düz kanal için ilk sıcaklık değișimi kanalın girișinden $0.1065 \mathrm{~m}$ uzaklıkta iken, B tipi kanatçıklı kanal için bu ilk sıcaklık değișimi $0.0472 \mathrm{~m}$ uzaklıkta olmaktadır. Ters akış için ise, $\mathrm{C}$ tipi kanatçık durumunda B tipi kanatçık durumuna göre ilk sıcaklık değişimi daha önce gelișme göstermektedir. Aynı zamanda, Şekil 11' den de görülebildiği gibi düz kanalla karşılaştırıldığında her iki kanatçık türü için de daha yüksek sıcaklık değerlerine ulașılmaktadır. Bu sonuçtan da anlașılabildiği üzere kanatçıkların kullanımı, akışın türbülans akımlarını ve ısı transfer yüzey alanını artırarak bir plakalı kanatçıklı isl değiștiricisinin ısı transfer performansını etkili bir şekilde artırabilmektedir.

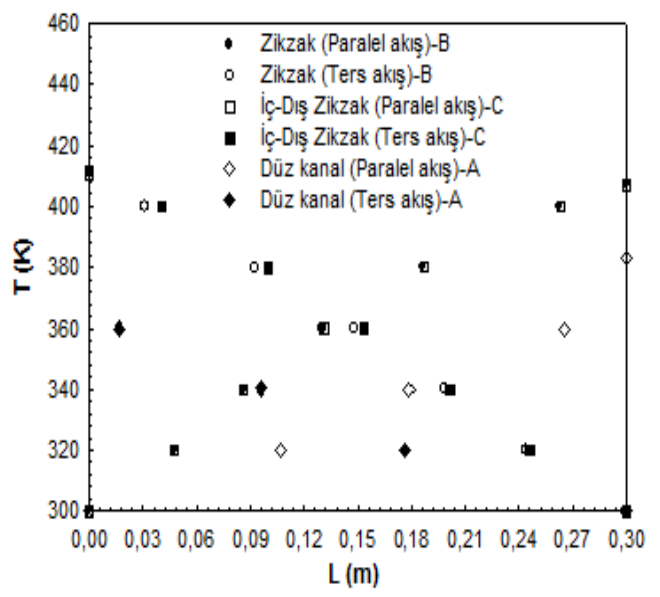

Şekil 11. Kanal yüzeyi boyunca paralel ve ters akış için soğuk akışkan sıcaklık değişimi

Şekil 13' de plakalı kanatçıklı ısı değiştiricilerde basınç düşümünün önemli olduğu kanatçıklı kısımlarda basınç dağılımlarının renklendirilmiş görselleri gösterilmiştir. Basınç dağılımlarından da görüldüğü gibi renk değişimi kanatçıklı kanallarda daha fazla
Şekil 12' de zikzak kanatçıklı kanal için paralel ve ters akış durumlarında kanatçık yüksekliğinin soğuk akıșkan sıcaklık değişimine olan etkisi gösterilmektedir. Kanatçık yüksekliğindeki artış, toplam ısı transfer yüzey alanını ve akışkan içindeki akıș dalgalanmalarını artırarak türbülansı artırmaktadır. Bu nedenle, her iki akış türünde de (paralel ve ters akış) e=4 mm kanatçık yüksekliğinde e=2 mm kanatçık yüksekliğine göre daha yüksek soğuk akışkan sıcaklık değerlerine ulaşılmaktadır. Paralel akış durumunda $\mathrm{e}=4 \mathrm{~mm}$ kanatçlk yüksekliğinde soğuk akıșkan çıkıș sıcaklığı 414,3 K iken bu değer e= $2 \mathrm{~mm}$ kanatçık yüksekliği için 410,7 K' dir. Ayrıca ters akıș durumunda, kanatçık yükseklik farkına bağlı sıcaklık farkı yaklaşık 4.1 K' i bulmaktadır. Fakat, tasarım açısından kanatçık yüksekliği seçilirken akışı engellemeyecek ölçüde olmasına dikkat edilmelidir.

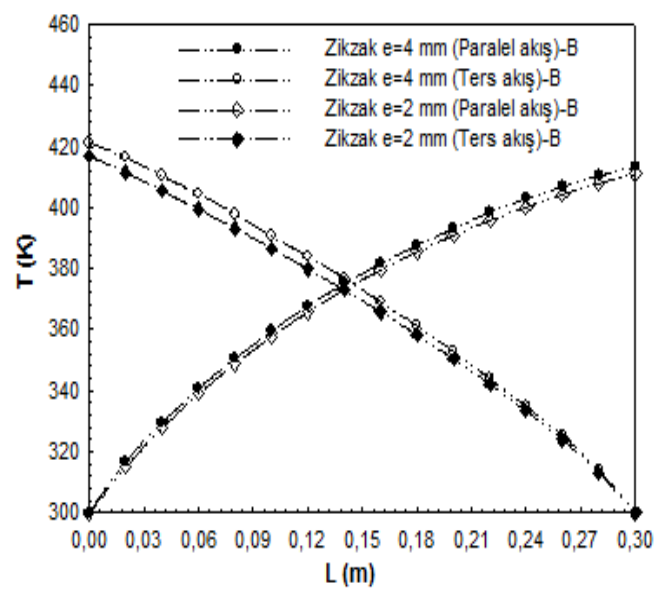

Şekil 12. Zikzak kanatçıklı kanalda e $=2 \mathrm{~mm}$ ve $\mathrm{e}=4 \mathrm{~mm}$ için paralel ve ters akış durumunda soğuk akışkan sıcaklık değişimi

olmaktadır. $\mathrm{Bu}$ durum da basınç düşümünün kanatçıklı kanallarda daha fazla olduğunu göstermektedir. Ayrıca, zikzak kanatçıklı kanalda basınç düşümünün iç-dış zikzak kanatçıklı kanaldan daha fazla olduğu Șekil 13' den görülebilmektedir. 


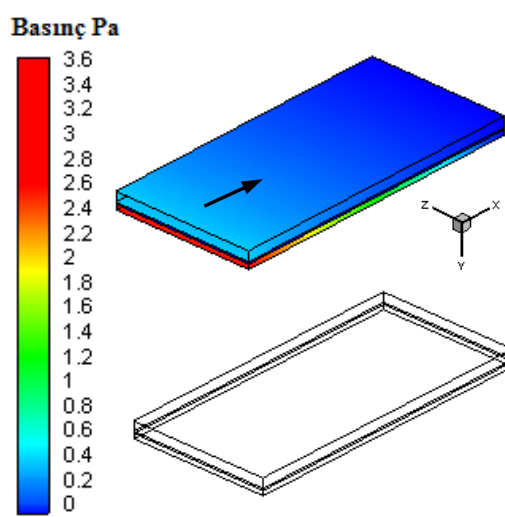

a)

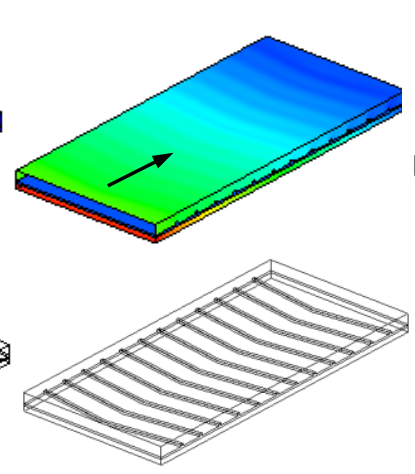

b)

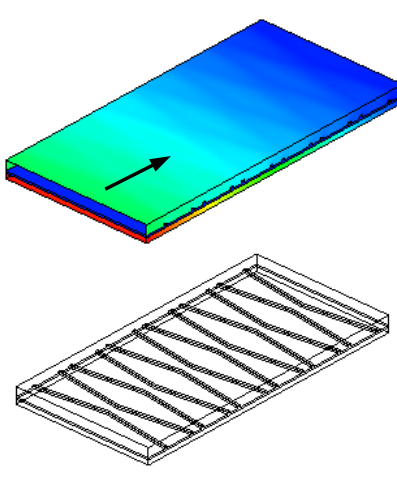

c)

Şekil 13. Basınç dağılımı a) Düz kanal b) Zikzak kanatçıklı kanal (e=2 mm)

c) İç-dış zikzak kanatçıklı kanal (e=2 mm)

Tablo 1' de plakalı ısı değiștiricilerinin kanal boyunca basınç düşüş değerleri gösterilmektedir. Elde edilen sonuçlar, $1.37 \mathrm{~Pa}$ ile en fazla basınç düşüşünün $2 \mathrm{~mm}$ kanatçık yüksekliğine sahip zikzak kanatçıklı kanalda olduğunu göstermektedir. Beklenildiği gibi kanal boyunca en az basınç düşüşü kanatçıksız düz kanalda elde edilirken, iç-dış zikzak kanatçıklı kanalda bu değer $1.318 \mathrm{~Pa}$ olmaktadır. Kanatçıkların ısı transferini artırmalarının yanında basınç düşüşünü ve dolayısıyla gerekli olan pompalama gücünü artırmaları nedeniyle kullanılan kanatçık tipine ve akış hızına dikkat etmek gerekmektedir.

Tablo 1. Plakalı ısı değiştiricilerinin basınç düşüşleri

\begin{tabular}{cc}
\hline Isı değiştiricisi tipi & Basınç düşüşü (Pa) \\
Düz kanal & 0.653 \\
Zikzak kanatçıklı kanal & 1.37 \\
İç-dış zikzak kanatçıklı kanal & 1.318 \\
\hline
\end{tabular}

\section{Sonuçlar}

Bu çalıșmada, zikzak ve iç-dıș zikzak olmak üzere iki farklı dikdörtgensel kanatçık geometrisine sahip plakalı isı değiştiricilerinde isı transferi, basınç düşüşü ve akış yapısı özellikleri üç boyutlu, zamandan bağımsız, sayısal olarak incelenmiştir. Çalıșmada ayrıca, kanatçık yüksekliğinin etkisi ve kanalın alt ve üst yüzeylerindeki akışkanların sıcaklık dağılımları da araştırılmıștır. Sıcaklık dağılımları ve basınç düşüşleri FLUENT paket programı kullanılarak görselleştirilmiştir. Pratikte yüksek basınç düşüşü ve dolayısıyla yüksek pompalama gücünden kaçınmak için genellikle düşük akış hızlarında çalışılmaktadır. Bu nedenle çalıșmada, düşük hızlarda kanatçık kullanımının ısı transferi üzerindeki etkisini görebilmek amacıyla Reynolds sayısının değeri 400 alınarak sonuçlar değerlendirilmiştir. Basınç düşüşü sonuçları analiz edildiğinde, 1.37 Pa ile en yüksek basınç düşüşünün zikzak kanatçıklı kanalda elde edildiği görülmektedir. Beklenildiği gibi kanal boyunca en az basınç düşüşü kanatçıksız düz kanalda elde edilirken, iç-dış zikzak kanatçıklı kanalda ise bu değer $\quad 1.318 \quad \mathrm{~Pa}$ olmaktadır. Kanatçıkların $\quad$ ISı transferini artırmalarının yanında basınç düşüşünü 
ve dolayısıyla gerekli olan pompalama gücünü artırmaları nedeniyle kullanılan kanatçık tipine ve akış hızına dikkat etmek gerekmektedir. Ayrıca, ters akış durumu yalnızca soğuk akışkanın akış yönü değiştirilerek elde edildiği için sıcak akışkanın geçtiği kanatçıklı kanaldaki basınç düşüşünde herhangi bir etkisi bulunmamaktadır. Bu nedenle, her

iki akış tipi için tek bir basınç düşüşü değeri bulunmaktadır. Bununla birlikte, farklı Reynolds sayılarının Nusselt sayısı üzerindeki etkisi de incelenmiş ve Re sayısındaki artışın, Nu sayısında artışa neden olduğu görülmüştür. Sonuçlar, soğuk akışkan sıcaklığının ters akış durumunda iç-dıș zikzak kanatçıklı kanalda düz kanala göre kanal çıkışında \% 8.4 ve zikzak kanatçık için \% 7.7, paralel akış durumunda ise zikzak kanatçlklı kanalda yine düz kanalla karşılaştırıldığında $\% \quad 7.6$ ve iç-dış zikzak kanatçıklı kanal için ise \% 6.8' lik artış elde edildiğini göstermektedir. Ayrıca, paralel akış durumunda $\mathrm{e}=4 \mathrm{~mm}$ kanatçılk yüksekliği ile e $=2 \mathrm{~mm}$ kanatçık yüksekliği karşılaştırıldığında soğuk akışkan çıkış sıcaklıkları arasındaki fark $3.6 \mathrm{~K}$ iken bu değer ters akış durumunda $4.1 \mathrm{~K}$ ' i bulmaktadır. Farklı kanatçı geometrilerini kıyaslamak bakımından, yapılan çalışmayla Karabulut vd. [11] tarafindan yapilan çalışmayı karşılaştıracak olursak, yapılan çalışmada 12 adet kanatçık ve $\mathrm{e}=2 \mathrm{~mm}$ kanatçık yüksekliğinde iç-dış zikzak kanatçık geometrisine sahip kanalda paralel akış durumunda kanal çıkışında soğuk akışkan sıcaklığı \% 6.8 artış gösterirken, ters akış durumunda \% 8.4 artış elde edildiği görülmektedir. Karabulut vd. [11] tarafindan yapılan diğer bir çalışmada ise $\mathrm{e}=4 \mathrm{~mm}$ kanatçık yüksekliği ve dış zikzak-düz-dış zikzak kanatçık geometrisine sahip plakalı kanatçılklı Isı değiştiricisinde kanatçılkların yerleştirilme durumları nedeniyle aynı ölçülere sahip kanalda 11 adet kanatçık bulunmaktadır. Bu çalışmada, kanatçık sayısının azaldığı fakat kanatçık yüksekliğinin $\mathrm{e}=2 \mathrm{~mm}$ den e=4 mm' ye çıktığı göz önüne alındığında paralel akış için soğuk akışkan sıcaklığının kanal çıkışında kanatçıksız düz kanala göre \% 8.35 arttı̆̆ fakat ters akış durumunda artış miktarının \% 8.4 ile yapılan çalışmaya eşit olduğu görülmektedir. Bu durum kanatçılk geometrisinin, yüksekliğinin ve sayısının ısı transfer miktarının artışı üzerinde önemli bir etkiye sahip olduğunu göstermektedir.

Literatürle karşılaştırıldığında benzer sonuçlar (Sunden [1], Wang vd. [14], Gupta vd. [17], Kayatas ve Ilbas [24]) elde edilmekle birlikte, yapılan çalışmada daha düşük Reynolds sayılarında, daha az sayıdaki ve literatürde yapılan çalışmalara göre tasarım yönünden daha basit kanatç̧klarla daha yüksek soğuk akışkan sıcaklıkları elde edilmektedir ki bu durum da isı transferinin daha iyi olduğunu kanıtlamaktadır.

Çalışmada, plakalı kanatçıklı ısı değiştiricileri için özgün kanatçık geometrileri değerlendirilmiş ve isI transferini artırmak için kullanılan kanatçlklar literatürde henüz araştırılmamıştır. $\mathrm{Bu}$ nedenle, plakalı kanatçıklı ısı değiştiricilerde daha fazla ısı transfer artış oranları elde edebilmek için bu tip dikdörtgensel kanatçık geometrilerinin isı transfer performans özelliklerinin araştırılması gereklidir. Çalışmada, kanatçık geometrisi ve yüksekliğinin değerlendirilmesiyle plakalı kanatçılklı ısı değiştiricilerinin verimliliğinin arttırılması amaçlanmıştır. Kanatçıklar, ısı aktarım yüzeylerini genişletmeleri ve oluşturacakları akış dalgalanmalarıyla aynı hacimde ısı aktarım miktarını arttırmak amacıyla tasarlanmaktadırlar. Bununla birlikte, kanatçıkların uygun şekilde kullanılmaması ısı geçişini artırmak yerine azaltabilir. Bu nedenle, 
E. Buyruk ve K. Karabulut / Plakalı Kanatçıklı Isı Değiștiricilerde Kanat Geometrisinin Isı Transferine Olan Etkisinin Üç Boyutlu Sayısal Olarak İncelenmesi

ince ve akışı engellemeyecek ölçüde sık aralıklı kanatçık tasarımının verimli olacağı söylenebilir. Sonuç olarak bu çalışmadan elde edilen verilerin, plakalı kanatçıklı ısı değiştiricilerinin tasarımı açısından yapılacak olan doğrudan uygulamalarda büyük öneme sahip olduğu ve plakalı kanatçıklı ısı değiştiricilerinde yoğun olarak kullanılan diğer kanatçık geometrilerinin optimizasyonunda kullanılabileceği düşünülmektedir.

\section{Semboller}

\begin{tabular}{|c|c|}
\hline$a$ & : kanatçık genișliği (mm) \\
\hline$b$ & : kanatçık aralığı (mm) \\
\hline$\Phi$ & : kanatçık açısı $\left({ }^{\circ}\right)$ \\
\hline$e$ & : kanatçık yüksekliği (mm) \\
\hline$H$ & : kanal yüksekliği (mm) \\
\hline$L$ & : kanal boyu (mm) \\
\hline$t$ & : katı yüzey kalınlığı (mm) \\
\hline$W$ & : kanal genişliği (mm) \\
\hline$D_{h}$ & : hidrolik çap (m) \\
\hline$h$ & : ısı taşınım katsayısı (W/m² K) \\
\hline$k$ & : ssıl iletkenlik katsayısı (W/m K) \\
\hline$V$ & : kanala giriș hızı (m/s) \\
\hline$\rho$ & : yoğunluk $\left(\mathrm{kg} / \mathrm{m}^{3}\right)$ \\
\hline$c_{p}$ & : özgül ısı (J/kg K) \\
\hline$p$ & : $\operatorname{basinç}\left(\mathrm{N} / \mathrm{m}^{2}\right)$ \\
\hline$T$ & : sicaklık $(\mathrm{K})$ \\
\hline$v$ & : kinematik viskozite $\left(\mathrm{m}^{2} / \mathrm{s}\right)$ \\
\hline$u, v, w$ & $\begin{array}{l}\mathrm{x}, \mathrm{y}, \mathrm{z} \quad \text { yönlerindeki } \\
\text { bileșenleri }(\mathrm{m} / \mathrm{s})\end{array}$ \\
\hline$u^{\prime}, v^{\prime}, w$ & $\begin{array}{l}\text { : x,y,z yönlerindeki dalgalanan } \\
\text { hız bileşenleri }(\mathrm{m} / \mathrm{s})\end{array}$ \\
\hline$\mu$ & : dinamik viskozite ( $\mathrm{kg} / \mathrm{s} \mathrm{m}$ ) \\
\hline$R e$ & : Reynolds sayısı (boyutsuz) \\
\hline $\mathrm{Nu}$ & : Nusselt sayısı (boyutsuz) \\
\hline$\phi$ & : viskoz kaybolma terimi $\left(\mathrm{m}^{2} / \mathrm{s}^{3}\right)$ \\
\hline$\mu_{t}$ & : türbülans viskozitesi (kg/s m) \\
\hline$k^{\prime}$ & : türbülans kinetik enerji $\left(\mathrm{m}^{2} / \mathrm{s}^{2}\right)$ \\
\hline$\varepsilon$ & $\begin{array}{l}\text { :türbülans disipasyon terimi } \\
\left(\mathrm{m}^{2} / \mathrm{s}^{3}\right)\end{array}$ \\
\hline
\end{tabular}

\section{İndisler}

$\begin{array}{ll}s & \text { : yüzey } \\ \infty & \text { : ortam } \\ h & : \text { sicak } \\ c & : \text { soğuk } \\ i & \text { : giriş }\end{array}$

$$
\begin{array}{ll}
1 & : \text { üst } \\
2 & : \text { alt } \\
- & \text { : zaman ortalaması }
\end{array}
$$

\section{Kaynakça}

[1] Sunden, B. 1999. Heat Transfer and Fluid Flow in Rib-Roughened Rectangular Ducts. ss 123-140. Kakaç, S., Bergles, A.E., Mayinger, F., Yüncü, H., ed. 1999. Heat Transfer Enhancement of Heat Exchangers, Kluwer Academic Publishers, Netherlands, 675s.

[2] Tauscher, R., Mayinger, F. 1999. Heat Transfer Enchancement in a Plate Heat Exchanger with RibRoughened Surfaces. ss 207-221. Kakaç, S., Bergles, A.E., Mayinger, F., Yüncü, H., ed. 1999. Heat Transfer Enhancement of Heat Exchangers, Kluwer Academic Publishers, Netherlands, 675s.

[3] Lee, C.K., Abdel-Moneim, S.A. 2001. Computational Analysis of Heat Transfer in Turbulent Flow Past a Horizontal Surface with TwoDimensional Ribs, International Communications in Heat and Mass Transfer, Cilt. 28, No.2, s. 161-170.

[4] Acharya, S., Dutta, S., Myrum, T.A., Baker, R.S. 1993. Periodically Developed Flow and Heat Transfer in a Ribbed Duct, International Journal of Heat and Mass Transfer, Cilt. 36, No. 8, s. 2069-2082.

[5] Liou, T.M., Chang, Y., Hwang, D.W. 1990. Experimental and Computational Study of Turbulent Flows in a Channel with Two Pairs of Turbulence Promoters in Tandem, ASME Journal of Fluids Engineering, Cilt. 112, No.3, s. 302310.

[6] Liou, T.M., Hwang, J.J. 1992. Developing Heat Transfer and Friction in a Ribbed Rectangular Duct with Flow Separation at Inlet, ASME Journal of Fluids 
E. Buyruk ve K. Karabulut / Plakalı Kanatçıklı Isı Değiştiricilerde Kanat Geometrisinin Isı Transferine Olan Etkisinin Üç Boyutlu Sayısal Olarak İncelenmesi

Engineering, Cilt. 114, No.3, s. 565573.

[7] Kaya, D., Buyruk, E., Can, A., Fertelli, A. 2007. Numerical Study of Heat Transfer Characteristics of Extended Surfaces, Strojarstvo, Cilt. 49, No. 2, s. 137-144.

[8] Buyruk, E., Karabulut, K., Karabulut, Ö.0. 2013. ThreeDimensional Numerical Investigation of Heat Transfer for Plate Fin Heat Exchangers, Heat and Mass Transfer, Cilt. 49, No. 6, s. 817-826.

[9] Buyruk, E., Karabulut, K. 2013. Numerical Investigation Into Heat Transfer for Three-Dimensional Plate Fin Heat Exchangers with Fins Placed Perpendicular to Flow, Transactions of Famena, Cilt. 37, No.2, s. 87-102.

[10] Buyruk, E., Karabulut, K. 2015. Numerical Study of Heat Transfer Enhancement and Flow Characteristics of ThreeDimensional Plate Fin Heat Exchangers, Heat Transfer Research, Cilt. 46, No. 9, s. 819-837.

[11] Karabulut, K., Buyruk, E., Kılınç, F., Karabulut, Ö.0. 2013. Farklı Geometrilerden Oluşan Kanatçıklı Plakalı Isı Değiștiricileri için Isı Transferinin Üç Boyutlu Sayısal Olarak İncelenmesi, 11. Ulusal Tesisat Müh. Kongresi, 17-20 Nisan, İzmir, 69-85.

[12] Ngo, T.L., Kato, Y., Nikitin, K., Ishizuka, T. 2007. Heat Transfer and Pressure Drop Correlations of Microchannel Heat Exchangers with S-shaped and Zigzag Fins for Carbon Dioxide Cycles, Experimental Thermal and Fluid Science, Cilt. 32, s. 560-570.

[13] Ganzarolli, M.M., Alternani, C.A.C. 2010. Optimum Fin Spacing and Thickness of a Finned Heat
Exchanger Plate, Heat Transfer Engineering, Cilt. 31, No. 1, s. 2532.

[14] Wang, Y.Q., Dong, Q.W., Liu, M.S., Wang, D. 2009. Numerical Study on Plate Fin Heat Exchangers with Plain Fins and Serrated Fins at Low Reynolds Number, Chemical Engineering\&Technology, Cilt. 32, No. 8, s. 1219-1226.

[15] Wen, J., Yang, H., Tong, X., Li, K., Wang, S., Li, Y. 2016. Optimization Investigation on Configuration Parameters of Serrated Fin in Plate-Fin Heat Exchanger Using Genetic Algorithm, International Journal of Thermal Sciences, Cilt. 101, s. 116-125.

[16] Masliyah, J.H., Nandakumar, K. 1976. Heat Transfer in Internally Finned Tubes, ASME Journal of Heat Transfer, Cilt. 98, No. 2, s. 257-261.

[17] Gupta, M., Kasana, K.S., Vasudevan, R. 2009. A Numerical Study of the Effect on Flow Structure and Heat Transfer of a Rectangular Winglet Pair in a Plate Fin Heat Exchangers, Journal of Mechanical Engineering Science, Cilt. 223, No. 9, s. 2109 2215.

[18] Salehi, S., Afshin, H., Farhanieh, B. 2015. Numerical Investigation of the Inlet Baffle, Header Geometry and Triangular Fins Effects on Plate-Fin Heat Exchangers Performance, Heat Transfer Engineering, Cilt. 36, No. 16, s. 1397-1408.

[19] Zhu, Y.H., Li, Y.Z. 2008. Three Dimensional Numerical Investigation on the Laminar Flow and Heat Transfer in Four Basic Fins of Plate Fin Heat Exchangers, ASME Journal of Heat Transfer, Cilt. 130, s. 1-8. 
E. Buyruk ve K. Karabulut / Plakalı Kanatçıklı Isı Değiştiricilerde Kanat Geometrisinin Isı Transferine Olan Etkisinin Üç Boyutlu Sayısal Olarak İncelenmesi

[20] Dixit, A., Patil, K. 2015. Heat

Transfer Characteristics of

Grooved Fin under Forced

Convection, Heat Transfer

Engineering, Cilt. 36, No. 16, s. 1409-1416.

[21] Wasewar, K.L., Hargunai, S., Atluri, P., Kumar, N. 2007. CFD Simulation of Flow Distribution in the Header of Plate Fin Heat Exchangers, Chemical Engineering\&Technology, Cilt. 30, No. 10, s. 1340-1346.

[22] Bhutta, M.M.A., Hayat, N., Bashir, M.H., Khan, A.R., Ahmad, K.N., Khan, S. 2012. CFD Applications in Various Heat Exchangers Design: A Review, Applied Thermal Engineering, Cilt. 32, s. 1-12.

[23] FLUENT User's Guide. 2003. Fluent Inc. Lebanon, $\mathrm{NH}$.

[24] Kayatas, N., Ilbas, M. 2005. İç İçe Borulu Model Bir Isı Değiștiricisinde Isı Transferinin İyileștirilmesinin Sayısal Olarak İncelenmesi, Erciyes Üniversitesi Fen Bilimleri Enstitüsü Dergisi, Cilt. 21, No. 1-2, s. 128-139. 